\title{
New experimental constraints: implications for petrogenesis of charnockite of dioritic composition
}

\author{
Rajib Kar ${ }^{1}$, Samarendra Bhattacharya ${ }^{2 *}$ \\ ${ }^{1}$ Jagannath Kishore College, Purulia, India; \\ ${ }^{2}$ Indian Statistical Institute, Kolkata, India; *Corresponding Author: samar.bhattacharya@gmail.com.
}

Received 13 August 2010; revised 16 September 2010; accepted 21 September 2010.

\begin{abstract}
Hornblende-dehydration melting experiments at high temperatures $\left(>950^{\circ} \mathrm{C}\right)$ indicate change of melt composition from tonalite/granodiorite to quartz-diorite; clinopyroxene instead of hornblende as the residual phase and change in melting reaction from peritectic hornblende-dehydration to eutectic clinopyroxene-orthopyroxeneplagioclase. In the light of these experimental results, petrogenesis of a charnockite pluton of homogeneous dioritic composition in the Eastern Ghats Belt, India, can be explained as melting at high-temperatures $\left(>950^{\circ} \mathrm{C}\right)$. Negative $\mathrm{Sr}$ and $\mathrm{Eu}$ anomalies further indicate plagioclase as a major residual phase, consistent with melting at high-temperatures $\left(>950^{\circ} \mathrm{C}\right)$.
\end{abstract}

Keywords: Dioritic charnockite; Residual clinopyroxene; Residual plagioclase; Eutectic melting

\section{INTRODUCTION}

It is quite common that large-scale charnockitic bodies are of variable composition from tonalite to granodiorite, and sometimes even dioritic composition is reported [1]. On the other hand, petrogenesis of massif-type charnockites have been variously described: a) mantlederived and differentiated melt [2]; b) high-temperature melting of dry granulite facies rocks [3]; c) more mafic varieties as mantle-derived melts [4]; d) product of hornblende-dehydration melting in the deep crust [5]. New melting experiments provide constraints on the petrogenesis of charnockitic rocks of dioritic composition. From the Jenapore area in the Eastern Ghats Belt, India, charnockite-massif was described as the product of hornblende-dehydration melting under granulite facies conditions, and with residual hornblende. There the two-pyroxene granulites occur as minor patches and bands and were explained as peritectic segregates [5]. A stock-like body of charnockite (pluton) occurs in the same locale, a few kilometer to the south (Lat: $20^{\circ} 46^{\prime} \mathrm{N}$; Long: $86^{\circ} 05^{\prime} \mathrm{E}$ ). In contrast to the charnockite-massif, it is of more mafic and homogeneous composition at the outcrop-scale and commonly has both orthopyroxene and clinopyroxene.

In the present communication we present geochemical data from the charnockite pluton and in the light of new experimental constraints explain its origin by melting at high-temperatures $\left(\geq 950^{\circ} \mathrm{C}\right)$.

\section{EXPERIMENTAL CONSTRAINTS}

The selected results of the hornblende-dehydration melting experiments is presented in Figure 1. The melts of $900^{\circ} \mathrm{C}$ and $925^{\circ} \mathrm{C}$ are tonalitic (normative Qtz / Plag > 0.25 ) and those above $950^{\circ} \mathrm{C}$ are quartz dioritic (normative Qtz / Plag < 0.25) in composition. The melt composition changes from corundum normative to diopside normative when temperature increases from $925^{\circ} \mathrm{C}$ to $950^{\circ} \mathrm{C}$. Also there is gradual decrease of plagioclase proportion with temperature rise. Moreover, the orthopyroxene and clinopyroxene are subequal in proportion at $900^{\circ} \mathrm{C}$, and orthopyroxene gradually decreases in proportion to a trace amount at $1100^{\circ} \mathrm{C}$. These results suggest that the nature of melting reaction changes from hornblende breakdown reaction at $925^{\circ} \mathrm{C}$ to eutectic clinopyroxeneorthopyroxene-plagioclase melting reaction at $950^{\circ} \mathrm{C}$ [6].

\section{CHARNOCKITE PLUTON}

The charnockite pluton at Jenapore is a relatively homogeneous body of two-pyroxene granulite, unlike those occurring as minor bands and patches within the massiftype charnockite described from the area to the north [5]. Also as distinct from those within massif-type charnockite garnet is absent, while clinopyroxene is much more abundant than orthopyroxene (Table 1). 
Mass Proportion of coexisting phases $\left(8 \mathrm{kbar}, 1 \% \mathrm{H}_{2} \mathrm{O}\right)$
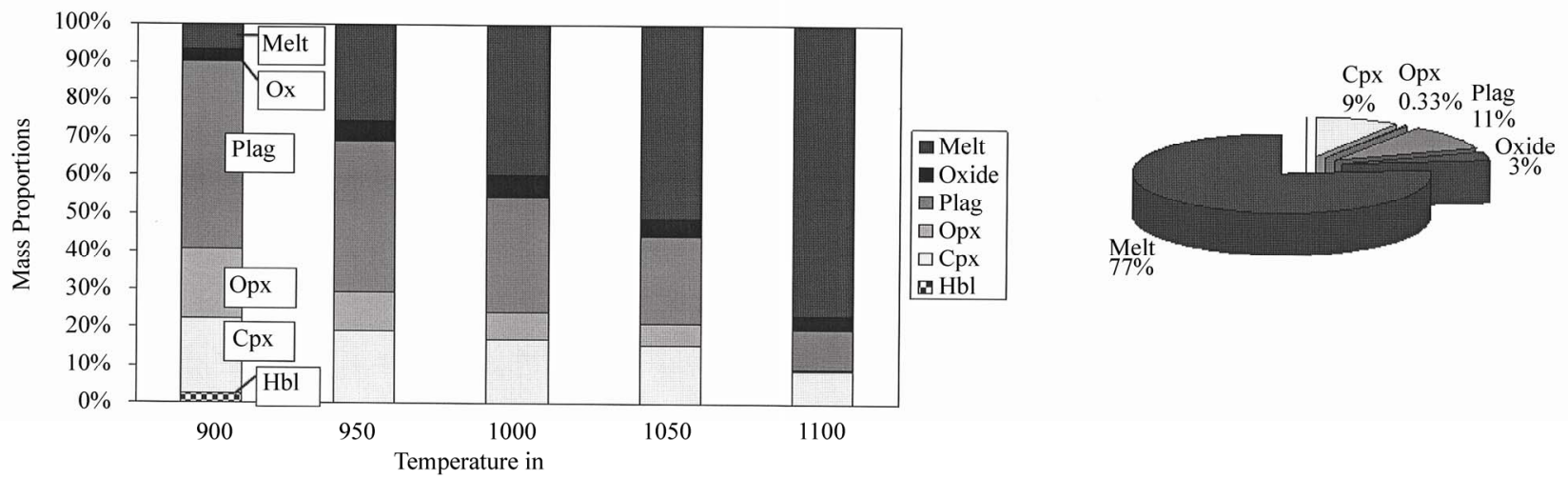

Figure 1. Mass proportions in melting experiments at $8 \mathrm{kbar}$.

Table 1. Modal mineralogy of the Charnockite pluton at Jenapore, Eastern Ghats Belt.

\begin{tabular}{|c|c|c|c|c|c|c|c|}
\hline Sample & JN35A & 2.J.95 & 2.J.82 & 2.J.90A & JN 194A & 2.J.50A & $\mathrm{JN} 35 \mathrm{~F}$ \\
\hline Quartz & 4.3 & 6.2 & 10.4 & 6.3 & 5.7 & 8.1 & 8.5 \\
\hline K-feldspar & 4.2 & 3.1 & 2.5 & 3.2 & 2.7 & 1.8 & 2.1 \\
\hline Plagioclase & 25 & 24.3 & 22.4 & 22.6 & 23.4 & 21.5 & 23 \\
\hline Orthopyroxene & 13.3 & 14.5 & 16.4 & 18.3 & 17.4 & 14.6 & 15.3 \\
\hline Clinopyroxene & 41.2 & 42 & 38.5 & 38.6 & 39.2 & 41 & 39.3 \\
\hline Hornblende & 2.5 & 3.1 & 1.5 & 1.7 & 3.4 & 4.2 & 3.8 \\
\hline Biotite & 5.4 & 3.7 & 5.2 & 4.6 & 3.9 & 4.5 & 5.3 \\
\hline Opaque & 2.2 & 3.1 & 1.5 & 3.4 & 2.7 & 3.2 & 2.5 \\
\hline Accessory & 1.2 & Trace & 1.1 & 0.7 & 1.4 & 0.4 & 0.3 \\
\hline
\end{tabular}

\subsection{Geochemistry}

\subsubsection{Analytical Procedure}

Both major and minor oxides as well as trace elements were analyzed by ICP-MS at the Australian Geological Survey Organization, Canberra. At AGSO the sample preparation for ICP-MS has been based on a method outlined in Jenner et al., 1990 [7]. However, some refractory elements like $\mathrm{Zr}$ have been problematic and to overcome this problem, a new method has been introduced. The new method involves digesting pieces of the lithium tetraborate/lithium metaborate fusions that have been prepared and run for XRF major element analysis. Approximately 100 micrograms of chips from the smashed discs are weighed accurately into Savillex Teflon vessels. Five milliliters of internal standard, one milliliter of $\mathrm{HF}$ and five milliliters of $\mathrm{HNO}_{3}$ are then added. The vessels are sealed and heated for twelve hours at $120^{\circ} \mathrm{C}$ on a timed hotplate, such that cooled samples are ready the following morning. The digests are then transferred to volumetric flasks and made up to volume ready for the ICPMS. The precision can be assessed from the $\mathrm{Zr}$ analysis (Table 2).

\subsubsection{Results}

The analytical data for the seven samples from the charnockite-pluton is presented in Table 3. In the Qz-OrPl diagram six (6) of the seven (7) analyzed samples plot in the field of Qz-diorite, while one sample plots in the field of Qz-monzodiorite (Figure 2). Normative quartz: plagioclase ratios vary between 0.02 and 0.15 and all the samples are diopside normative, varying between 6.4 and 11.7. All these features are compatible with the new experimental constraints indicating high temperature melting $\left(\geq 950^{\circ} \mathrm{C}\right)$ in mafic rocks. Moreover, these compositional characteristics (homogeneous) suggest a change of melting reaction from peritectic to eutectic, as in the recent melting experiment [6].

The incompatible elements like $\mathrm{K}, \mathrm{Rb} \& \mathrm{Ba}$ are enriched, while $\mathrm{Ti}$ and base metals like $\mathrm{Cr} \& \mathrm{Ni}$ are depleted

Table 2. Comparative $\mathrm{Zr}$ analysis in ppm.

\begin{tabular}{lcccc}
\hline Standards & $\begin{array}{c}\text { ICP-MS } \\
\text { old }\end{array}$ & $\begin{array}{c}\text { ICP-MS } \\
\text { new }\end{array}$ & $\begin{array}{c}\text { AGSO } \\
\text { XRF }\end{array}$ & $\begin{array}{c}\text { Recommended } \\
{[8]}\end{array}$ \\
\hline W-2 & 78 & 95 & 93 & 94 \\
BIR-1 & 15 & 15 & 15 & 15.5 \\
DNC-1 & 36 & 37 & 36 & 41 \\
QLO-1 & 171 & 189 & 188 & 185 \\
BHVO-1 & 151 & 176 & 175 & 179 \\
AGV-1 & 205 & 235 & 235 & 227 \\
\hline
\end{tabular}


Table 3. Composition of the charnockite pluton of Jenapore, Eastern Ghats, India.

\begin{tabular}{|c|c|c|c|c|c|c|c|}
\hline Area & Jenapore & & & & & & \\
\hline Sample & $\mathrm{JN} 35 \mathrm{~A}$ & 2.J.95 & 2.J.82 & 2.J.90A & JN 194A & 2.J.50A & $\mathrm{JN} 35 \mathrm{~F}$ \\
\hline $\mathrm{SiO}_{2}$ & 49.69 & 52.03 & 54.42 & 52.19 & 52.74 & 52.87 & 53.05 \\
\hline $\mathrm{TiO}_{2}$ & 2.9 & 1.72 & 1.53 & 1.34 & 0.97 & 1.11 & 1.71 \\
\hline $\mathrm{Al}_{2} \mathrm{O}_{3}$ & 13.85 & 15.53 & 15.09 & 15.74 & 16.58 & 16.63 & 15.29 \\
\hline $\mathrm{Fe}_{2} \mathrm{O}_{3}$ & 2.38 & 1.36 & 1.75 & 1.08 & 1.46 & 0.75 & 1.71 \\
\hline $\mathrm{FeO}$ & 13.64 & 9.44 & 9.18 & 8.85 & 8.01 & 7.78 & 8.8 \\
\hline $\mathrm{MnO}$ & 0.22 & 0.16 & 0.16 & 0.15 & 0.14 & 0.13 & 0.15 \\
\hline $\mathrm{MgO}$ & 3.75 & 5.5 & 4.75 & 6.46 & 6.94 & 6.07 & 5.16 \\
\hline $\mathrm{CaO}$ & 7.9 & 8.19 & 7.28 & 8.48 & 8.51 & 8.68 & 8.05 \\
\hline $\mathrm{Na}_{2} \mathrm{O}$ & 1.14 & 2.78 & 2.96 & 2.73 & 2.3 & 2.26 & 2.97 \\
\hline $\mathrm{K}_{2} \mathrm{O}$ & 2.07 & 1.51 & 1.56 & 1.26 & 1.06 & 1.87 & 1.79 \\
\hline $\mathrm{P}_{2} \mathrm{O}_{5}$ & 0.75 & 0.42 & 0.37 & 0.28 & 0.21 & 0.3 & 0.41 \\
\hline LOI & 1.54 & 1.28 & 0.86 & 1.37 & 0.98 & 1.47 & 0.81 \\
\hline Total & 99.83 & 99.92 & 99.91 & 99.93 & 99.9 & 99.92 & 99.9 \\
\hline \multicolumn{8}{|c|}{ Trace elements in ppm } \\
\hline $\mathrm{Cr}$ & 9 & 119 & 105 & 185 & 98 & 205 & 78 \\
\hline $\mathbf{N i}$ & 8 & 50.5 & 33.5 & 37.5 & 20 & 49 & 24 \\
\hline $\mathbf{N i}$ & 8 & 50.5 & 33.5 & 37.5 & 20 & 49 & 24 \\
\hline Sc & 45 & 31.5 & 31.5 & 33.5 & 32 & 31 & 34 \\
\hline $\mathbf{V}$ & 263 & 193 & 162 & 170 & 167 & 160 & 184 \\
\hline $\mathbf{C u}$ & 36 & 26 & 26 & 20 & 22 & 22 & 19 \\
\hline $\mathbf{Z n}$ & 176 & 120 & 127 & 104 & 97 & 89 & 114 \\
\hline $\mathbf{Z n}$ & 176 & 120 & 127 & 104 & 97 & 89 & 114 \\
\hline $\mathbf{T i}$ & 17400 & 10320 & 9180 & 8040 & 5820 & 1660 & 10260 \\
\hline $\mathbf{K}$ & 8588 & 6265 & 6472 & 5228 & 4338 & 7759 & 7427 \\
\hline $\mathbf{R b}$ & 48 & 54 & 54.5 & 34 & 40 & 56 & 49 \\
\hline $\mathbf{B a}$ & 1527 & 727 & 734 & 736 & 376 & 1066 & 1076 \\
\hline $\mathrm{Sr}$ & 341 & 327 & 296 & 325 & 314 & 376 & 324 \\
\hline $\mathbf{Z r}$ & 329 & 255 & 226 & 177 & 117 & 197 & 257 \\
\hline Nb & 35.3 & 25.3 & 24.8 & 15.5 & 11.6 & 17 & 24.1 \\
\hline Th & 2.46 & 1.98 & 1.51 & 2.83 & 8.84 & 1.49 & 3.72 \\
\hline $\mathbf{U}$ & 0.41 & 0.3 & 0.48 & 0.32 & 0.56 & 0.27 & 0.5 \\
\hline La & 92.7 & 55.3 & 44.9 & 47.5 & 56 & 56.2 & 64.2 \\
\hline $\mathrm{Ce}$ & 234 & 120 & 97.2 & 97 & 115 & 115 & 135 \\
\hline Pr & 22.7 & 13.1 & 11 & 10.4 & 11.8 & 12.2 & 14.8 \\
\hline Nd & 87.7 & 50.3 & 43 & 39.4 & 42.8 & 45.2 & 55.7 \\
\hline Sm & 15.5 & 9.45 & 8.23 & 7.06 & 7.55 & 7.29 & 9.85 \\
\hline $\mathbf{E u}$ & 3.87 & 2.26 & 2.13 & 1.99 & 1.6 & 2.21 & 2.58 \\
\hline Gd & 15 & 8.92 & 8.33 & 7.05 & 6.96 & 7.14 & 9.2 \\
\hline Tb & 2.28 & 1.37 & 1.32 & 1.11 & 1.06 & 1.07 & 1.43 \\
\hline Dy & 12.9 & 7.83 & 7.5 & 6.32 & 5.98 & 5.96 & 8.01 \\
\hline Ho & 2.8 & 1.69 & 1.64 & 1.4 & 1.29 & 1.28 & 1.76 \\
\hline $\mathbf{E r}$ & 8.11 & 4.74 & 4.74 & 4.09 & 3.63 & 3.64 & 5.07 \\
\hline $\mathbf{Y b}$ & 6.88 & 4.07 & 3.99 & 3.57 & 3.2 & 3.22 & 4.33 \\
\hline Lu & 1.01 & 0.59 & 0.59 & 0.52 & 0.47 & 0.46 & 0.65 \\
\hline$\sum$ REE & 505.45 & 279.62 & 234.57 & 227.41 & 257.34 & 260.87 & 312.58 \\
\hline$(\mathbf{L a} / \mathbf{S m})_{\mathbf{N}}$ & 3.76 & 3.68 & 3.43 & 4.23 & 4.67 & 4.85 & 4.10 \\
\hline$(\mathbf{G d} / \mathbf{L u})_{\mathbf{N}}$ & 1.85 & 1.88 & 1.76 & 1.69 & 1.84 & 1.93 & 1.76 \\
\hline $\mathbf{E u} / \mathbf{E} u^{*}$ & 0.19 & 0.19 & 0.19 & 0.21 & 0.17 & 0.23 & 0.20 \\
\hline
\end{tabular}

(Figure 3). These features suggest a melt character for these dioritic charnockites. However, $\mathrm{Zn}$ is significantly enriched and could be related to clinopyroxene as a ma- jor phase, which commonly contains trace amounts of $\mathrm{Zn}$. Similar degrees of enrichment in $\mathrm{Rb} \& \mathrm{Sr}$ relative to primitive mantle is consistent with partial melting in ma- 


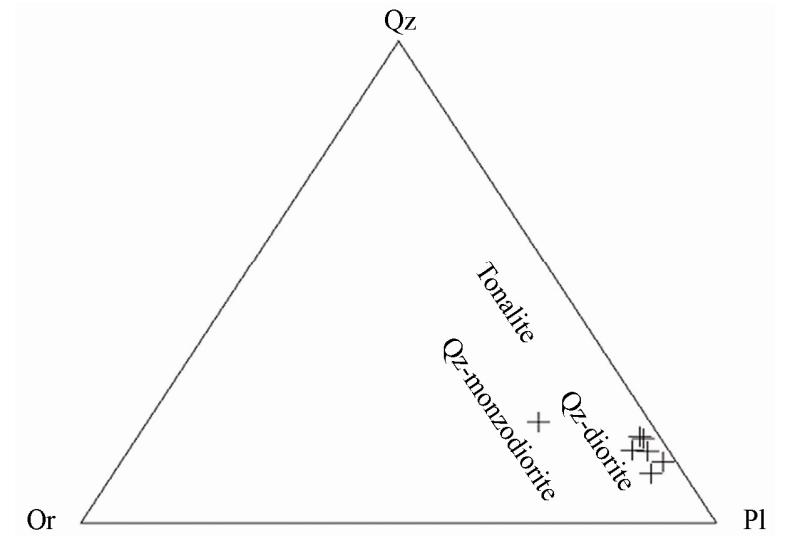

Figure 2. Normative Qz-Or-Pl diagram for the charnockites.

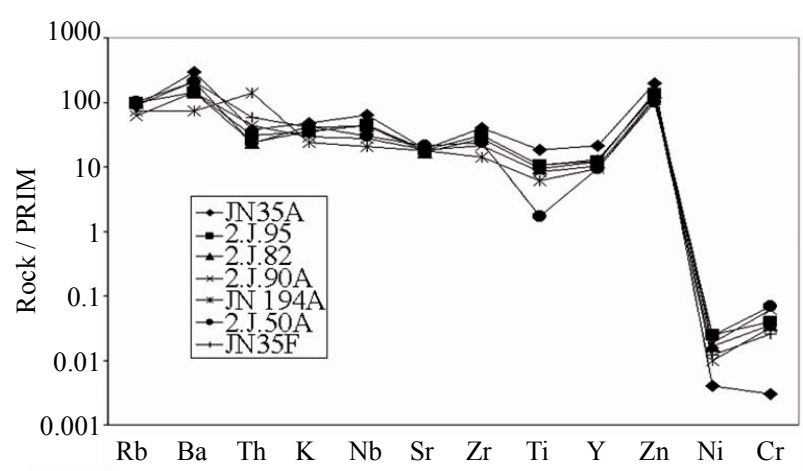

Figure 3. Multi-element spider diagram for the charnockites. Normalizing values from Taylor and McLennan, 1985 [23].

fic rocks involved in the break down of hornblende and plagioclase. However, unlike the tonalitic charnockites (cf. Figure 9 in [5]), negative $\mathrm{Sr}$ anomaly in the dioritic charnockites here implies plagioclase as a major residual phase [9]. $\mathrm{Zr}$ contents between $117 \& 329$ are variable, but most of the samples have near saturation concentration. This and relatively high Th (between $1.49 \& 8.84$ ppm) and U (between $0.27 \& 0.56 \mathrm{ppm})$ suggest interaction between melt and restitic zircon. Also unlike the tonalitic charnockites, total REE contents are high, between $227 \& 505$ ppm, suggests near saturation concentration. Relatively less HREE fractionation $(\mathrm{Gd} / \mathrm{Yb})_{\mathrm{N}}$, between $1.69 \& 1.88$ than LREE fractionation $(\mathrm{La} /$ $\mathrm{Sm})_{\mathrm{N}}$, between $3.43 \& 4.85$, suggests melt-pyroxene coexistence. Significant negative Eu anomaly is characteristic of these charnockites of quartz-dioritic composition unlike those in the tonalitic charnockites and Archaean tonalites $[5,10]$ suggests major residual plagioclase (Figure 4). This is also consistent with the signature of negative $\mathrm{Sr}$ anomaly.

\section{DISCUSSIONS}

The Eastern Ghats Mobile Belt, along the east coast of

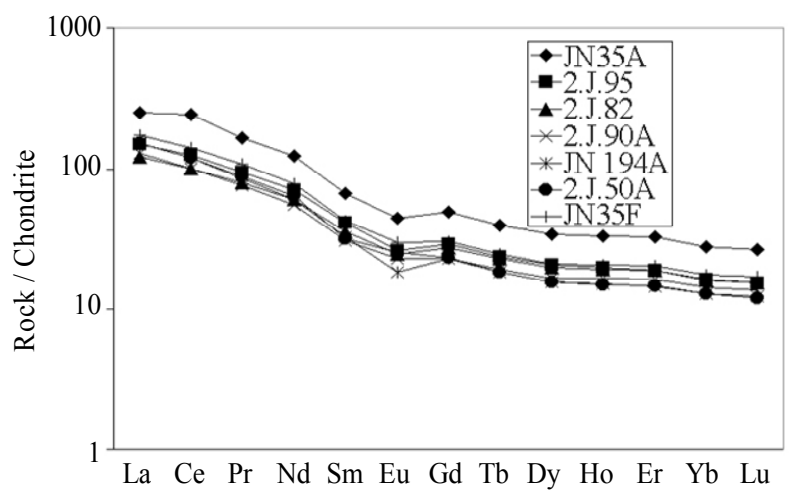

Figure 4. Chondrite normalized REE diagram for the charnockites. Normalizing values from Taylor and McLennan, 1985 [23].

peninsular India, is commonly described as a collisional orogen [11]. Extremely high temperatures $\left(>900^{\circ} \mathrm{C}\right)$ have been recorded from different granulite lithologies and from different parts of this regional granulite terrain [12-16]. On the other hand, dehydration melting experiments provided important constraints on the petrogenesis of massif-type charnockitic rocks of tonalitic and granodioritic compositions [17-20]. The latest experiments of hornblende-dehydration melting at high-temperatures $(\geq$ $950^{\circ} \mathrm{C}$ ), indicate changing melt composition from tonalite /granodiorite to quartz-diorite, along with residual clinopyroxene instead of hornblende [6]. In this context it is important to note that this is the first report of charnockite pluton of dioritic composition in the Eastern Ghats Belt. Erstwhile magmatic charnockite or their protoliths are described as enderbite, of tonalitic composition [21-22]. The tonalitic to granodioritic charnockitemassif of Jenapore was described as the product of hornblende-dehydration melting with residual hornblende \& or garnet by Kar et al. [5]. In the same locale a stock-like body of charnockite, its quartz-dioritic composition with residual clinopyroxene and plagioclase provide evidence of high-temperatures $\left(>950^{\circ} \mathrm{C}\right)$. This is also consistent with the proposed change in the melting reaction from peritectic hornblende-dehydration melting to eutectic clinopyroxene-orthopyroxene-plagioclase melting.

\section{CONCLUSIONS}

1) This is the first report of dioritic charnockite pluton in the Eastern Ghats Belt.

2) Yet another evidence of Ultra-high temperature crustal metamorphism in the Eastern Ghats Belt.

3) Negative $\mathrm{Sr}$ and Eu anomalies, unlike those of tonalitic charnockites and Archaean tonalites, imply plagioclase as a major residual phase. 


\section{ACKNOWLEDGEMENTS}

Melting experiments at the Petrological Laboratory of the Zurich Institute was supported by a Swiss Federal Fellowship to RK. Analytical data by ICP-MS were acquired by courtesy Dr. J.W. Sheraton.

\section{REFERENCES}

[1] Young, D.N., Zhao, J.X., Ellis, D.J. and McCulloch, M.T. (1997) Geochemical and Sr-Nd isotopic mapping of source provinces for the Mawson charnockites, east Antarctica: Implications for Proterozoic tectonics and Gondwana reconstruction. Precambrian Research, 86, 1-19.

[2] Subba Rao, M.V. and Divakara Rao, V. (1988) Chemical constraints on the origin of the charnockites in the Eastern Ghat Mobile Belt, India. Chemical Geology, 69, 3748.

[3] Zhao, J., Ellis, D.J., Kilpatrick, J.A. and McCulloch, M.T. (1997) Geochemical and Sr-Nd isotopic study of charnockites and related rocks in the northern Prince Charles Mountain, East Antarctica. Precambrian Research, 81, 37-66.

[4] Sheraton, J.W, Tindle, A.G. and Tingey, R.J. (1996) Geochemistry, origin, and tectonic setting of granitic rocks of the Prince Charles Mountains, Antarctica. Australian Journal of Geology \& Geophysics, 16, 345-370.

[5] Kar, R., Bhattacharya, S. and Sheraton, J.W. (2003) Hornblende dehydration melting in mafic rocks and the link between massif-type charnockite and associated granulites, Eastern Ghats Granulite Belt, India. Contributions to Mineralalogy and Petrology, 145, 707-729.

[6] Kar, R. (2010) Melting experiments in the NCFMASH system at 8 kbar: Implications for the origin of mafic granulites. Indian Journal of Geology, Special Issue on Geodynamic Regimes, Global tectonics and evolution of Precambrian cratonic basins in India, 80, 71-80.

[7] Jenner, G.A., Longerich, H.P., Jackson, S.E. and Fryer, B. J. (1990) ICP-MS a powerfull tool for high-precision trace element analysis in earth science: Evidence from analysis of selected USGS reference samples. Chemical Geology, 83, 133-148.

[8] Govindaraju, K. (1994) 1994 compilation of working values and sample description for 383 geostandards. Geostandards Newsletter, 18, 1-158.

[9] Tarney, J., Wyborn, L.E.A., Sheraton, J.W. and Wyborn, D. (1987) Trace element differences between Archaean, proterozoic and phanerozoic crustal components: Implications for crustal growth processes. In: Ashwal, L.D. Ed., Workshop on the Growth of Continental Crust, Lunar and Planetary Institute, 139-140.

[10] Nutman, A.P., McGregor, V.R., Friend, C.R.L., Bennet, V. C. and Kinny, P.D. (1996) Itsaq gneiss complex of southern west Greenland; the world's most extensive record of early crustal evolution (3,900-3,600 Ma). Precambrian
Research, 78, 1-39.

[11] Santosh, M., Maruyama, S. and Sato, K. (2009) Anatomy of a Cambrian suture in Gondwana: Pacific-type orogeny in southern India? Gondwana Research, 16, 321-341.

[12] Lal, R.K., Ackermand, D. and Upadhyay, H. (1987) P$\mathrm{T}-\mathrm{X}$ relationships deduced from corona textures in sapphirine-spinel-quartz assemblages from Paderu, southern India. Journal of Petrology, 28, 1139-1168.

[13] Dasgupta, S., Sengupta, P., Fukuoka, M. and Bhattacharya, P.K. (1991) Mafic granulites in the Eastern Ghats, India: Further evidence for extremely high temperature crustal metamorphism. Journal of Geology, 99, 124-133.

[14] Bhowmik, S.K., Dasgupta, S., Hoernes, S. and Bhattacharya, P.K. (1995) Extremely high-temperature calcareous granulites from the Eastern Ghats, India: Evidence for isobaric cooling, fluid buffering, and terminal channelized fluid flow. Europian Journal of Mineralogy, 7, 689-703.

[15] Sen, S.K., Bhattacharya, S. and Acharyya, A. (1995) A multi-stage pressure-temperature record in the Chilka Lake granulites: The epitome of the metamorphic evolution of Eastern Ghats, India? Journal of Metamorphic Geology, 13, 287-298.

[16] Bhattacharya, S. and Kar, R. (2002) High-temperature dehydration melting and decompressive P-T path in a granulite complex from the Eastern Ghats, India. Contributions to Mineralogy and Petrology, 143, 175-191.

[17] Patino Douce, A.E. and Beard, J.S. (1995) Dehydration melting of biotite gneiss and quartz amphibolite from 3 to 15 kbar. Journal of Petrology, 36, 707-738.

[18] Springer, W. and Seck, H.A. (1997) Partial fusion of basic granulites at 5 to $15 \mathrm{kbar}$ : Implications for the origin of TTG magmas. Contributions to Mineralogy and Petrology, 127, 30-45.

[19] Lopez, S. and Castro, A. (2001) Determination of the fliud-absent solidus and supersolidus phase relationships of MORB-derived amphibolites in the range 4-14 kbar. American Mineralogist, 86, 1396-1403.

[20] Sisson, T.W., Ratajeski, K. and Hankins, W.B. (2005) Voluminous granitic magmas from common basaltic sources. Contributions to Mineralogy and Petrology, 148, 635661.

[21] Rickers, K., Mezger, K. and Raith, M. (2001) Evolution of the continental crust in the Proterozoic Eastern Ghats Belt, India and new constraints for Rodinia reconstruction: Implications from $\mathrm{Sm}-\mathrm{Nd}, \mathrm{Rb}-\mathrm{Sr}$ and $\mathrm{Pb}-\mathrm{Pb}$ isotopes. Precambrian Research, 112, 183-210.

[22] Bhui, U.K., Sengupta, P. and Sengupta, P. (2007) Phase relations in mafic dykes and their host rocks from Kondapalle, Andhra Pradesh, India: Implications for the timedepth trajectory of the Paleoproterozoic (late Archean?) granulites from southern Eastern Ghats Belt. Precambrian Research, 156, 153-174.

[23] Taylor, S.R. and McLennan, S.M. (1985) The continental crust: Its composition and evolution. Blackwell, Oxford. 